\title{
The Ripening of Local Papaya Cultivars Under Controlled Conditions'
}

\author{
A. J. Rodriguez, R. Guadalupe, and L. M. Iguina de George ${ }^{2}$
}

\section{INTRODUCTION}

The cultivation of papaya (Carica papaya L.) in Puerto Rico was once an important agricultural activity, but susceptibility to "bunchy top" and mosaic virus and lack of adequate outlets for the fruit have reduced its production. Although infection can be kept to a minimum with proper pest control, local production of the fruit is still very low and industry has resorted to importing green fruit to supply the ever-increasing demand for raw material.

Ripe papaya production for the local fresh-fruit market and for processing is presently negligible because this fruit is very susceptible to spoilage after ripening even under favorable conditions. There is, however, a large potential market for the ripe fruit as well as for processing into jellies, jams, ice cream mixes, custards, and drinks. Formulations for these products and processing facilities to prepare them are available to the local food industry but processors still lack adequate papaya cultivars that might be used for producing high-quality products. Moreover, information is lacking on the ripening of papayas under controlled condiditions, so important for a steady processing line.

This paper presents information developed pertaining to procedures for ripening locally grown papaya cultivars by the application of ethylene gas under controlled temperatures and humidities.

\section{LITERATURE REVIEW}

Information for ripening of fruit by applying low concentrations of ethylene gas is quite abundant. Von Loesecke and Simmonds $(13,16)$

1 Manuscript submitted to Editorial Board August 16, 1973.

2 Chemical Engineer, Assistant Horticulturist, and former Assistant Food Technologist, respectively, Food Technology Laboratory, Agricultura] Experiment Station, Mayagüez Campus, University of Puerto Rico, Río Pjedras, P.R. The authors express their appreciation to I. Beauchamp de Caloni, Assistant Food Technologist, O. Parsi Ros, Research Assistant, D. Alcalá Frasqueri, Associate Bacteriologist and L. A. Lefebre de González, former Assistant Food Technologist, for their helpful cooperation in the performance of the plant and laboratory work; and to G. Colom Covas, Associate Horticulturist, J. A. Rodríquez Garcia, Research Assistant at Corozal Substation, J. Badillo Feliciano, Assistant Agronomist at Isabela Substation, and A. Acosta Matienzo, Associate Agronomist at Gurabo Substation, for their assistance in conducting the field work. 
reviewed the methods for ripening bananas, indicating humidity range, ethylene dosification, room ventilation and temperature which are adequate for the ripening of the fruit stored in an airtight chamber. Marloth (11) reported the successful ripening of mangos by the application of ethylene at a temperature range of $70^{\circ}$ to $80^{\circ} \mathrm{F}$ and a humidity of 85 to 90 percent. In an early reference by Harvey (7), the use of ethylene under controlled temperature and humidity were regarded as essential factors in the control of fruit ripening. The author presents specific information for ripening bananas, pineapples, tomatoes, and dates. Papayas are merely listed among the tropical fruits that could be ripened by the application of the gas but no further details are offered in relation to this fruit. Stevenson (14) also outlined a general procedure for the artificial coloring and ripening of fruits by using either ethylene, acetylene gas, coal gas, or a kerosene burner. He mentioned papayas among the fruits that can be colored or ripened by this procedure and stated that $85^{\circ}$ to $90^{\circ} \mathrm{F}$ is the best temperature range to carry on the process.

The physical and chemical changes that take place during the ripening of papayas have not been discussed extensively in the literature. Chemical composition of foreign papaya cultivars has been reported by Thompson (15), Biale (6), Bhutiani et al. (5), and others. Jones (8) studied chemical changes in the Solo variety stored under different temperatures. Jones and IKubota (9) reported the extent of the sucrose hydrolysis that takes place during ripening. These authors found a significant increase in the total soluble solids of the fruit during the process. Wardlaw et al. (17) have shown a marked increase in the production of carbon dioxide occurs in papayas at the beginning of the ripening process that reaches a high level (climacteric peak) at full ripeness. They also showed that the carbon dioxide content of the fruit cavity increases with maturity.

Studies to extend the shelf life of papayas of the Solo variety intended for shipping have been conducted in Hawaii $(1,2,3,4)$. Akamine et al. (3) found an effective reduction in the incidence of post-harvest decay in papayas by treating the fruit with hot water $\left(110^{\circ}\right.$ to $120^{\circ} \mathrm{F}$ for $20 \mathrm{~min}$ utes). Akamine (1) studied the effects of $\mathrm{CO}_{s}$ on the quality and shelf life of papaya and reported that untreated fruit may tolerate up to 30 percent of $\mathrm{CO}_{2}$ in a modified atmosphere when stored for 5 to 6 days at $76^{\circ}$ to $83^{\circ}$ F. He obtained typical respiratory curves for mature-green fumigated papayas ripened at $77^{\circ} \mathrm{F}$, and also found that the hot water treatment increased respiration and accelerated the onset of the climacteric rise associated with increased rate of ripening.

Bhutiani et al. (5) in relation to the harvesting of papayas mentions the physical changes that take place in the latex as a criterion of maturity. 
This is the only reference found in the literature regarding the use of undestructive methods for picking papayas at a full mature-green stage.

\section{MATERIALS AND METHODS}

Commercial papayas were used in the initial phase of this study. The fruit selected was representative of the type of raw material commonly processed in the green stage by the local preserve industry. The fruits in general were of unknown varietal identity with variable sizes and weights ranging from 2.0 to 5.0 pounds per fruit. Differences in pulp color and aroma occurred commonly among them. For harvesting this type of papayas, local producers use fruit size rather than stage of maturity as the criterion for picking. Field observations were made on fruit growth, physical changes in fruit latex, and peel color of fruits from commercial papaya seedlings in experimental plots. Fruit growth was determined by measuring the major and minor axes of the fruits until constant values were obtained in consecutive determinations and thereafter.

The study on the ripening of papayas was continued with fruits of more uniform quality and characteristics from Station cultivars P.R. 6-65, P.R. 7-65 and P.R. 8-65. These cultivars differed notably. Cultivar P.R. 6-65 bear fruits weighing from 2.5 to 4.0 pounds each. Fruits of P.R. 7-65 are of medium size weighing in the range of 2.0 to 3.0 pounds. Fruits of P.R. 8-65 are smallest of these cultivars, weighing only from 1.0 to 2.0 pounds each. Ripe fruits of P.R. 6-65 and P.R. 8-65 have orange-yellow pulps. The fruit pulp color of P.R. 7-65 varies from an orange-red to a red shade. Fruit samples from these cultivars were harvested by observing the changes in the fruit latex and the appearance of a color break near the apex as an indication of complete growth and maturity.

Ripening runs were conducted in a room of about 1,000 cubic feet in which temperature, humidity and air-flow could be controlled within preset limits. A bunk door, and an exhaust fan installed in an upper corner of the room, provided ventilation as required. Ethylene gas was applied at the rate of 1 part per 1,000 cubic feet of room space per application with additional dosages as required per experiment.

The effects of ethylene on commercial papayas were determined by placing untreated fruit in 55-gallon steel drums equipped with loosely fitted covers. The drums were provided with a valve for applying the gas. These drums were stored in a room under constant temperature. Ethylene also was applied to commercial fruits placed in stainless steel trays stored in the room at pre-set conditions. Unless otherwise indicated, fruits for all these experiments were pretreated with hot water and placed in stainless steel trays in the ripening room 24 hours after harvesting. The hot water 
treatment (3) was adopted as a standard practice to reduce fruit storage decay and consisted of dipping the fruits in hot water at $120^{\circ} \mathrm{F}$ for 20 minutes followed by cooling with tap water.

Fruit ripening was appraised in terms of the amount of colored skin observed, and evaluated by an arbitrary scale which ranged from 0 (fully green) to 4 (fully yellow). The fully yellow fruits were left in the ripening room an additional day or two until they attained edible qualities for sensory evaluation. Samples were scored using the Kramer and Ditman scale (10) in which +2 means acceptable and -2 not acceptable.

Chemical analyses generally were performed on composite samples of three or four fruits representing different ripening stages. Single fruits were analyzed occasionally to record individual differences.

\section{INITIAL TRIALS}

The first trials in these investigations were undertaken to evaluate the storage behavior, and ascertain the quality of ripened fruits produced by the common types of papayas available in the local market. These fruits were stored for ripening at ambient conditions, $86^{\circ} \mathrm{F}\left(30^{\circ} \mathrm{C}\right)$ and 65 to 67 percent relative humidity, without ventilation provided or ethylene gas applied. After several trials, results showed that a large proportion of the fruits in the various lots presented clear indications of color changes with strong evidence of moisture loss. Very few of the fruits could be considered truly ripe, however, and most softened and decayed before becoming fully colored.

\section{ETHYLENE TRIALS}

Due to the unsuccessful ripening of the papaya samples under the aforementioned conditions, the effect of ethylene on the ripening of this type of fruit was investigated by applying the gas in dosages of $1: 1,000$ to papayas in 55-gallon steel drums stored in the ripening room at $80^{\circ} \mathrm{F}$ $\left(26.7^{\circ} \mathrm{C}\right)$ and 90 percent relative humidity. Trials were also conducted in which ethylene was applied to fruits placed in stainless steel trays and stored in the ripening room at the same temperatures and humidities. Results of these tests were very discouraging as low yields of unevenly colored papayas with a high incidence of fruit decay were generally obtained. Commercial papayas showed a high degree of resistance to ripening even with the application of ethylene. The abnormal behavior during ripening was attributed to the immaturity of the fruit at the time of picking. This condition was more marked in young than in more mature fruits. In addition, quality of fruits that became fully colored was generally rated poor by tasters. 


\section{GRADE OF MATURITY TRIALS}

Investigations then were directed toward the development of information on papaya harvesting to determine the grade of maturity at which they should be picked for good quality ripened fruit. Fruits were harvested at different ages, as determined from fruit set, and these were stored for ripening at $80^{\circ} \mathrm{F}\left(26.7^{\circ} \mathrm{C}\right)$ and 85 percent relative humidity. When they attained the proper edible quality, samples were submitted to a panel of

TABLE 1.-Effecl of age and maturity of commercial papayas at the time of picking on the flavor quality of the fruils ripened at $80^{\circ} \mathrm{F}$ and 85 -percent relative humidity

\begin{tabular}{|c|c|c|c|c|c|c|}
\hline Agel & $\begin{array}{c}\text { Maturity at } \\
\text { picking }\end{array}$ & $\begin{array}{c}\text { Soluble } \\
\text { solids }\end{array}$ & $\begin{array}{l}\text { Total } \\
\text { sugars }\end{array}$ & $\begin{array}{c}\text { Reducing } \\
\text { sugars }\end{array}$ & $\begin{array}{l}\text { Non- } \\
\text { reducing } \\
\text { sugars }\end{array}$ & $\begin{array}{l}\text { Sensory } \\
\text { evaluation after } \\
\text { storage }\end{array}$ \\
\hline Days & & Percent & Percent & Percent & & Remarks \\
\hline 105 & Green & 3.8 & 3.74 & 3.68 & 0.06 & - \\
\hline 112 & Do. & 4.1 & 3.56 & 3.53 & .03 & - \\
\hline 119 & Do. & 4.5 & 3.96 & 3.79 & .17 & - \\
\hline 126 & Do. & 4.7 & 3.81 & 3.76 & .05 & $\begin{array}{l}\text { Insipid flavor, } \\
\text { no aroma }\end{array}$ \\
\hline 133 & $\begin{array}{l}\text { Slight color } \\
\text { changes }\end{array}$ & 5.2 & 4.46 & 4.26 & .20 & Do. \\
\hline 140 & $\begin{array}{l}\text { Yellow spots, } \\
\text { latex chang- } \\
\text { ing }\end{array}$ & 6.3 & 5.45 & 5.21 & .24 & Do. \\
\hline 147 & Do. & 6.5 & 5.66 & 5.43 & .23 & $\begin{array}{l}\text { Acceptable but } \\
\text { low sugar } \\
\text { content }\end{array}$ \\
\hline 154 & $1 / 4$ ripe & 7.2 & 6.54 & 6.32 & .22 & Do. \\
\hline 161 & 32 ripe & 8.1 & 7.33 & 7.20 & .13 & Do. \\
\hline 168 & 1/2 ripe & 8.6 & 7.34 & 7.17 & .17 & Do. \\
\hline 175 & Fully ripe & 9.7 & 8.58 & 8.40 & .18 & Acceptable \\
\hline
\end{tabular}

1 After fruit set.

tasters for sensory evaluation. Data on soluble solids and sugar content, age and grade of maturity at picking, and data on sensory evaluation of the samples, is presented in table 1 . The table shows that fruits fully green in color with milky latex harvested 105 to 119 days from fruit set ripened unevenly and were of low quality. Full coloration and fairly good appearance was obtained, however, in fruits 126 to 140 days old that had been stored for 8 days under the conditions mentioned above, but their flavor was insipid and without aroma. According to field observations, papayas attain full growth after 126 to 140 days, as shown by actual measurement while on the trees. Papayas 126 days old showed no apparent changes in peel color or fruit latex, although such changes started to show in about 
133 days. Distinct variations in connection therewith were definitely noted, however, in fruits 140 days old or over. The best fruit quality was scored by the tasters in samples picked at 147 to 175 days, although remarks were annotated concerning the low sugar content of the fruits.

The data related to the chemical analysis of the fruits as picked, which appears in table 1, shows that the sugars were almost exclusively present in their reducing form as evidenced by the small differences between total and reducing sugar values (non reducing sugars). That a larger hydrolysis of sucrose occurs in ripe fruit than in green (9) was not established clearly in this local papaya strain. The total soluble solids, however, showed a marked increase during ripening.

The data obtained from tests with commercial papayas pointed to the importance of adequate harvesting and fruit quality as essential factors in successful fruit ripening. Work with this type of material was discontinued due to difficulties in standardizing fruit quality for application of other treatments under test.

Papaya of more uniform quality and characteristics from the Station's cultivars P.R. 6-65, 7-65 and 8-65 were used during the remainder of the investigation.

\section{VENTILATION TRIALS}

A set of experiments was designed to determine the effect of ventilation on the rate of ripening of papayas, as ventilation is a standard procedure for expelling the $\mathrm{CO}_{2}$ gas from the storage room in commercial fruit-ripening processes.

The tests were conducted with untreated mature green fruits stored for ripening at $77^{\circ} \mathrm{F}(1)$ and 85 to 90 percent relative humidity. No ethylene gas was applied to accelerate the process. Fruit lots were ventilated for periods of 5 to 30 minutes per experiment following a preset schedule of ventilation of the chamber. The information obtained is presented in table 2. The results show a relationship between the yields of ripe fruit and the total amount of ventilation applied to each lot. The amount of ventilation is expressed as a percentage of the total storage time for each individual fruit lot. It should be noticed that highest yields were obtained in runs during which there was the least amount of ventilation. On the other hand, hyperventilation of the lot, i.e., 0.44 percent or higher, resulted in extremely few ripened fruit.

The effect of room ventilation also was studied using hot water-treated fruits (3) of the P.R. 8-65 cultivar stored in the chamber under conditions prevailing in the previous experiment. The data in table 3 presents the information obtained from nonventilated runs in which the fruit lots were subjected to the effect of short ventilation periods. In general, yields shown 
in table 3 are superior to those shown in table 2. In addition to higher yields, fruit of better quality was obtained in a shorter storage interval with hot water-treated than with untreated fruit. The experiment did not establish a definite trend as to the effects of short ventilation periods on the yield of ripe fruit, but the data shows a notable increase in yield in 80 percent of the nonventilated runs.

TABLE 2.-Effect of room ventilation on the ripening of untreated papayas P.R. 6-65, P.R. 7-65, and P.R. 8-65 stored at $77^{\circ} F$. and 85 to 90 percent relative humidity

\begin{tabular}{cccc}
\hline Fruits per lot & Total storage time & $\begin{array}{c}\text { Ventilation ratio: } \\
\text { interval length } \\
\text { total storage time }\end{array}$ & Yield ripe fruit \\
\hline Number & Days & 0.10 & Percent \\
55 & 6.6 & .14 & 67.0 \\
55 & 7.0 & .20 & 67.0 \\
68 & 8.0 & .20 & 75.0 \\
42 & 9.75 & .44 & 48.0 \\
71 & 8.75 & .46 & 22.0 \\
51 & 6.0 & 1.70 & 36.0 \\
55 & 9.75 & 2.10 & 33.0 \\
47 & 7.75 & & 15.0 \\
\hline
\end{tabular}

TABLE 3.-Effect of room ventilation on the ripening of hot water-treated papayas of the cultivar P.R. 8-65 stored at $77^{\circ} F$ and 85 to 90 relative humidity

\begin{tabular}{cccc}
\hline Fruits per lot & Total storage time & $\begin{array}{c}\text { Ventilation ratio: } \\
\text { interval length } \\
\text { total storage time }\end{array}$ & Yield ripe fruit \\
\hline Number & Days & & Percent \\
55 & 6.0 & 0.0 & 87.0 \\
39 & 5.75 & .0 & 100.0 \\
52 & 6.0 & .0 & 72.0 \\
70 & 6.0 & .0 & 89.0 \\
119 & 6.0 & .0 & 86.0 \\
63 & 6.0 & .06 & 76.0 \\
62 & 6.0 & .06 & 73.0 \\
43 & 6.0 & .12 & 53.0 \\
63 & 6.0 & .24 & 74.0 \\
\hline
\end{tabular}

ETHYLENE CONCENTRATION TRLALS

A series of experiments were conducted to determine the effect of ethylene on the rate of ripening and the most adequate concentration of the gas to accelerate ripening. Composite lots containing fruits of the three cultivars were stored for ripening at $77^{\circ} \mathrm{F}\left(25^{\circ} \mathrm{C}\right)$ and a high degree of relative humidity. The gas was applied in the range of dosages used most commonly for fruit ripening. After 24 hours of storage, the gas was applied to the 
nonventilated lots in one of the following concentrations: $1 / 1,000,1 / 2,500$ and 1/5,000 (cubic foot of gas per cubic feet room space). The results of these tests are presented in table 4 . The yields are expressed as percent of sound fully ripe fruits obtained for each particular cultivar. The ripe fruit counts were made for storage periods of the same duration (6 to 7 days each). The data shows the best yield of ripe fruit was obtained when ethylene was applied at the rate of $1: 1,000$. The gas treatments were found more favorable to P.R. 8-65 papayas than to other cultivars. Fruit size apparently was a limiting factor in unevenly ripening of P.R. 6-65 and 7-65 as percentages of partially ripened and decayed fruits were higher in both cultivars, the fruit of which are of large and medium size. Observations on the ripening behavior of papayas weighing in the range 3.0 to 5.0

TaBle 4.-Percentage yields of ripe fruits obtained at similar storage interval by applying ethylene gas at three different concentrations to papaya cultivars P.R. 6-65,

P.R. 7-65, and P.R. 8-65 stored at $77^{\circ} F$ and 85 to 90 percent relative humidity

\begin{tabular}{ccccc}
\hline \multirow{2}{*}{$\begin{array}{c}\text { One ethylene } \\
\text { dosage per run }\end{array}$} & Storage time & \multicolumn{3}{c}{ Yield of sound fully colored fruits } \\
\cline { 3 - 5 } & & P.R. 6-65 & P.R. 7-65 & P.R. 8-65 \\
\hline Ratio & Days & Percent & Percent & Percent \\
& 6.5 & 55.0 & 50.0 & 75.0 \\
$1: 1,000$ & 7.0 & 60.0 & 50.0 & 80.0 \\
& 7.0 & 50.0 & 45.0 & 79.0 \\
\hline \multirow{2}{*}{$1: 2,500$} & 7.0 & 45.0 & 45.0 & 58.0 \\
& 7.0 & 50.0 & 52.0 & 70.0 \\
\hline \multirow{2}{*}{$1: 5,000$} & 7.0 & 30.0 & 15.0 & 55.0 \\
& 6.75 & 48.0 & 35.0 & 68.0 \\
\hline
\end{tabular}

pounds tend to indicate that large and medium size fruits require a longer storage period for ripening uniformly than smaller fruits weighing from 1.0 to 2.0 pounds. Susceptibility of large-sized green papayas to bruising from handling results in a larger display of injuries earlier in the ripening process than in smaller sized P.R. 8-65 fruits.

In addition to testing the concentrations of ethylene best suited to induce ripening in mature green papayas, experiments were conducted to determine the eflect of ethylene on the fruits stored at $77^{\circ} \mathrm{F}$ and 90 percent relative humidity when the gas was applied at two different storage intervals. The results are given in table 5 and these include data on gas concentration and intervals of application as well as yields and total storage time per run. Yield data in this table do not point out the most favorable storage interval for the application of the gas when treated runs are compared to controls, but the ratio (yield/total time (days)) indicates 
the beneficial effects of ethylene application on the rate of ripening of papaya fruits.

The effect of ethylene on ripening of papayas was investigated further with fruit lots stored under conditions outlined in the previous experiment during which ethylene dosages were applied at different storage intervals. The data derived from these experiments is presented in table 6. Results

TABLE 5.-Effect on yield of ripe fruit and on length of storage of the application of ethylene at the rate of $1: 1,000$ at different storage intervals to non-ventilated lots stored at $77^{\circ} F$ and 90-percent relative humidity (var. P.R. 8-65)

\begin{tabular}{ccccc}
\hline Fruits per run & $\begin{array}{c}\text { Ethylene }(1: 1,000) \\
\text { time interval }\end{array}$ & Ripe fruit yield & Storage time & $\begin{array}{c}\text { Ratio: yield (percent)/ } \\
\text { total time (dnys) }\end{array}$ \\
\hline Number & Bours & Percenl & Days & \\
49 & Control & 77.6 & 10.0 & 7.76 \\
44 & Control & 75.0 & 9.0 & 8.30 \\
40 & 24 & 90.0 & 7.0 & 12.6 \\
56 & 24 & 75.0 & 8.0 & 9.4 \\
62 & 48 & 98.4 & 9.0 & 10.9 \\
48 & 48 & 73.0 & 7.0 & 10.4 \\
52 & 48 & 67.3 & 7.0 & 9.6 \\
\hline
\end{tabular}

TABLE 6.-Yields of ripe fruit obtained by application of ethylene at rate of $1: 1000$ to nonventilated lots at different storage intervals stored at $77^{\circ} \mathrm{F}$ and 85 to 95 percent relative humidity

\begin{tabular}{cccc}
\hline Fruits per lot & $\begin{array}{c}\text { Ethylene (1:1,000) } \\
\text { storage interval }\end{array}$ & Storage time & Yield ripe fruit \\
\hline Number & Hours & Days & Percent \\
58 & 24 & 7.75 & 100.0 \\
60 & 24,48 & 7.75 & 90.0 \\
42 & 24,48 & 7.75 & 95.0 \\
40 & 48,72 & 7.50 & 90.0 \\
50 & 48,72 & 7.75 & 94.0 \\
50 & $24,48,72$ & 7.75 & 96.0 \\
45 & $24,48,72$ & 7.00 & 85.0 \\
\hline
\end{tabular}

again failed to indicate clear relationships between ripe fruit yields and frequency of ethylene application, but indicated the favorable effect of the multiple application of the gas on the rate of ripening. The differences between the yields in tables 5 and 6 might be due to the degree of maturity of the papayas at time of picking. With regard to the response of the fruit to ethylene, the fully grown, well-matured papayas showed the effect of the gas much earlier than the younger and less mature ones during ripening. There are indications that $a$ single application of the gas might be necessary to trigger the ripening reaction, but a practical procedure for ripening 
papayas requires at least a second ethylene application 24 hours after the first to cope with the individual differences in maturity of fruits.

From the standpoint of ripe papaya production, data has been presented favoring the nonventilation of the lots to produce highest yields of fruit. The possible employment of unskilled operators to run the rooms for the ripening of the fruit, however, has posed the important problem of safety in the operation of the rooms. Ethylene is a highly flammable gas that forms explosive mixtures with air at concentrations of 3 percent. This requires that extreme care be exercised to avoid overcharging of rooms with the gas. While the concentrations of ethylene for papaya ripening are very small and well below the explosive limit for the gas-air mixture, there is a possibility that gas may be accumulated at higher concentrations in isolated

TABLE 7.-Effect of 5 -minute ventilation periods on length of storage and yields of papaya lots stored at $77^{\circ} \mathrm{F}$ and 85 to 90 percent relative humidity with two 1:1,000 ethylene applications

\begin{tabular}{|c|c|c|c|c|c|}
\hline \multirow[b]{2}{*}{$\begin{array}{l}\text { Fruit weight } \\
\text { per lot }\end{array}$} & \multicolumn{5}{|c|}{ Ventilations } \\
\hline & $\begin{array}{l}\text { Ethylene } \\
\text { applications } \\
\text { per run }\end{array}$ & $\begin{array}{l}\text { Periods } \\
\text { per run }\end{array}$ & Storage intervals & $\begin{array}{l}\text { Yield ripe } \\
\text { fruit }\end{array}$ & $\begin{array}{c}\text { Length storage } \\
\text { time }\end{array}$ \\
\hline Pounds & Hours & Number & Hours & Percent & Days \\
\hline 325 & 24,48 & 0 & No & 84.5 & 7.0 \\
\hline 285 & do & 0 & No & 88.2 & 6.0 \\
\hline 250 & do & 1 & 24 & 86.5 & 6.5 \\
\hline 265 & 24,48 & 2 & 24,48 & 75.8 & 7.0 \\
\hline 255 & do & 2 & 24,48 & 87.1 & 6.75 \\
\hline 280 & do & 3 & $24,48,72$ & 82.7 & 6.5 \\
\hline 290 & 24,48 & 3 & $24,48,72$ & 93.4 & 7.0 \\
\hline
\end{tabular}

parts of the room and thus constitute a hazard. Further information on the effect of short ventilation on the rate of ripening and yields was thus collected from plant runs in which mature-green and color-turning fruits were ripened at $77^{\circ} \mathrm{F}$ and 85 to 90 percent relative humidity, and to which two dosages of ethylene were applied at 24- and 48-hour storage periods. The chamber was ventilated according to a preestablished schedule, as follows: Nonventilated runs to be used as a control, runs ventilated after 24 hours of storage, runs ventilated after 24 and 48 hours, and runs ventilated after 24, 48 and 72 hours. Each ventilation period consisted of a 5minute operation of an extractor fan with the bunk door of the room opened. The results of the ripening tests are presented in table 7. As shown by the data, no definite trend is observed among the yields of ripe fruits when compared among themselves. No evidence was found of any harmful effect from the short periods of ventilation of the room, on the length of the storage period or on the quality of the ripened fruits. 


\section{JOURNAL OF AGRICULTURE OF UNIVERSITY OF PUERTO RICO}

Data on the chemical analyses of P.R. 8-65 papayas, harvested at different ages of the fruits, is presented in table 8. These fruits were stored for ripening at $77^{\circ} \mathrm{F}$ and 85 to 90 percent relative humidity. Ethylene at the rate of $1: 1,000$ and ventilation were applied to the fruits after 24 and 48 hours. Analyses of tree-ripened fruits is also included in table 8 for comparison purposes. It should be noted that maturity ratings as deter-

\section{TABLE 8.-Chemical analyses performed on artificially ripened and tree-ripened papayas of the P.R. 8-65 cultivar}

\begin{tabular}{|c|c|c|c|c|c|c|c|}
\hline \multirow{2}{*}{$\mathrm{Age}^{2}$} & \multirow{2}{*}{$\begin{array}{c}\text { Fruitz } \\
\text { maturity } \\
\text { affer } \\
\text { storage }\end{array}$} & \multirow{2}{*}{ Soluble solids } & \multirow{2}{*}{$\mathrm{pH}$} & \multirow{2}{*}{ Acidity } & \multicolumn{2}{|c|}{ Sugars } & \multirow{2}{*}{ Humidity } \\
\hline & & & & & Reducing & Total & \\
\hline Days & & Percent & & Percenl & Percent & Percent & Percent \\
\hline \multicolumn{8}{|c|}{ Artificially ripened } \\
\hline 140 & 3.5 & 8.3 & 4.63 & 0.22 & 7.31 & 7.20 & 89.75 \\
\hline 147 & 3.0 & 9.1 & 4.52 & 0.21 & 7.41 & 7.41 & 88.94 \\
\hline 147 & 4.0 & 10.5 & 4.50 & 0.23 & 8.99 & 8.95 & 87.68 \\
\hline 154 & 4.0 & 12.5 & 4.35 & 0.23 & 10.15 & 10.44 & 85.72 \\
\hline 161 & 3.5 & 9.3 & 4.68 & 0.24 & 7.71 & 7.81 & 88.86 \\
\hline 168 & 3.0 & 8.9 & 4.52 & 0.21 & 6.76 & 6.98 & 89.50 \\
\hline 168 & 4.0 & 11.3 & 4.50 & 0.29 & 9.09 & 9.39 & 86.75 \\
\hline \multicolumn{8}{|c|}{ Tree-ripened fruits } \\
\hline 147 & 4.0 & 9.8 & 4.95 & 0.21 & 7.51 & 7.63 & 88.63 \\
\hline 154 & 4.0 & 10.0 & 4.92 & 0.18 & 7.52 & 7.82 & 89.16 \\
\hline 161 & 4.0 & 13.1 & 4.68 & 0.22 & 10.69 & 10.82 & 85.57 \\
\hline 168 & 4.0 & 13.2 & 4.78 & 0.25 & 10.96 & 10.96 & 85.63 \\
\hline
\end{tabular}

${ }^{1}$ Fruits were ripened at $77^{\circ} \mathrm{F}$ and 85 to 90 percent relative humidity with two applications of ethylene at the rate of 1:1,000 after ventilating the chamber for 5-minute period after 24 and 48 hours of storage.

2 From fruit set.

"Fruit maturity scale: $0,1,2,3$ and 4, where 0 means "full green" and 4 means "fully colored".

mined by appraising the color of the fruit peels do not correspond to the chronological age of the specimens. Information in the table indicates a possible relation between state of maturity and ripening of the papayas, $\mathrm{pH}$ values and acidity level of the samples. Irrespective of their age, $\mathrm{pH}$ values are below 5.00 for all the fruits in the range of maturity between 3 and 4, while for green and color-turning papayas $\mathrm{pH}$ values are usually above 5.00 , with the acidity level in less than 0.18 percent. It should be noticed that there is no difference in their chemical analyses when tree- 
ripened fruits of maturity 4 are compared with ethylene-ripened fruit of the same grade of maturity.

\section{SUMMARY}

Studies were conducted to determine a suitable procedure for ripening local papaya cultivars for the local fresh fruit market and for processing. Varietal characteristics and harvesting at the proper stage of maturity proved essential factors for producing high quality ripened papayas. Green papayas from local markets were found to ripen unevenly with impaired quality. Changes in the fruit latex and observations in peel color changes were used as criteria for picking papayas at their optimum maturity. The following ripening procedure was successful in ripening the fruit from local papaya cultivars: Properly harvested fruits were dipped in a hot water bath at $120^{\circ} \mathrm{F}$ for 20 minutes, followed by a tap water rinse to cool them. The treated papayas were placed in stainless steel trays in an airtight chamber at $77^{\circ} \mathrm{F}$ and 85 to 95 percent humidity. The chamber was exhausted for 5 minutes after 24 and 48 hours of storage. An ethylene application at the rate of 1:1,000 followed each chamber ventilation period. Papayas from cultivar P.R. 8-65 ripened into good quality fruits in 6 to 7 days under these conditions.

\section{RESUMEN}

Se realizaron estudios en busca de un procedimiento adecuado para la maduración de la fruta de la papaya de variedades locales destinada al mercado local de fruta fresca y para fines de elaboración. Se determinó que para poder obtener fruta madura de alta calidad es esencial tomar en cuenta tanto el factor de la variedad como el del grado adecuado de desarrollo de la fruta al cosecharse. Para los fines de los estudios, las muestras de fruta se cosecharon usando como criterios los cambios en el color de la cáscara tanto como en el látex, que varía de lechoso a acuoso. Para la maduración de las papayas cultivadas localmente se aplic6 con éxito el siguiente procedimiento: Las frutas que se consideraron en estado óptimo de crecimiento se trataron con agua caliente a $120^{\circ} \mathrm{F}$ por 20 minutos y luego se enfriaron con agua corriente. Las frutas asi tratadas se colocaron en bandejas de acero inoxidable y se almacenaron en la cámara de maduración a una temperatura de $77^{\circ} \mathrm{F}$ y una humedad relativa de 85 a 95 por ciento. La cámara se ventiló por 5 minutos a las 24 y a las 48 horas de iniciada la prueba. Después de cada periodo de ventilación de la fruta, se aplicaron dosis de etileno a razón de 1:1,000. Se obtuvo fruta madura de buena calidad de la variedad P.R. 8-65, después de estar almacenada por 667 días bajo las condiciones ya descritas.

\section{LITERATURE CITED}

1. Akamine, E. K., Effect of carbon dioxide on quality and shelf life of papaya, Hawaii Agr. Exp. Sta. Tech. Prog. Rept. No. 120, January 1959.

2. - Respiration of fruits of papaya (Carica papaya, L., var. Solo) with reference to the effect of quarantine disinfection treatments, Amer. Soc. Hort. Sci. 89: 231-36, 1967. 
3. - and Arisumi, T., Control of post harvest storage decay of fruits of papaya (Carica papaya, L.) with special reference to the effect of hot water, Proc., Amer. Soc. Hort. Sci. 61: 270-74, 1953.

4. Arisumi, T., Test shipments of papayas with special reference to storage decay control, Hawaii Agr. Exp. Sta. Tech. Bull. 29, 1956.

5. Bhutiani, R. C., Shankar, J. V., and Kutty Menon, P.G., Papaya, Central Food Technological Research Institute, Mysore India, Industrial Monograph No. 2, pp. 41, July 1963.

6. Biale, J. B., Advances in Food Res. Academic Press, New York and London, 10: 293-354, 1960.

7. Harvey, R. B., Artificial ripening of fruits and vegetables, Agr. Exp. Sta., Univ. Minnesota, Bull. 247, October 1928.

8. Jones, W. W., Respiration and chemical changes of the papaya fruit in relation to temperature, Plant Physiol. $17: 481,1942$.

9. - and Kubota, H., Some chemical and respirational changes in the papaya fruit during ripening, and the effects of cold storage on these changes, Plant Physiol. 15: 711-17, 1940.

10. Kramer, A., and Ditman, L. P., A simplified variable taste panel method for detecting flavor changes in vegetables treated with pesticides, Food Technol. $19(3)$ : 155-59, 1956.

11. Marloth, R. H., The mango in South Africa 1. Soil and climatic requirements and varieties, Farm. in S. Afr. 22: 457-63, 1947.

12. Official Methods of Analysis of the Association of Official Agricultural Chemists (A.O.A.C.), 10th ed., Washington, D. C., 1965.

13. Simmonds, N. W., Bananas, Longmans, Green and Co., Ltd., London, England, pp. 214-20, 1965.

14. Stevenson, C. C., Artificial colouring and ripening of fruits, Queensland, Agr. J. 78: 151-5, 1954.

15. Thompson, A., The composition of Hawaiian fruits and nuts, Hawaii Agr. Exp. Sta. Rep. 1,914: 62-75, 1915.

16. Von Loesecke, H. W., Bananas Interscience Publishers Inc., New York, N. Y., pp. 39-66, 1949.

17. Warlaw, C. W., and Leonard, E. R., The storage and physiology of tropical fruits, Trop. Agr. 12: 313-19, 1935. 